\title{
DAMIAN PUŚLECKI*
}

ORCID: 0000-0002-3363-649X

\section{Zasiłek opiekuńczy dla rolników i domowników ubezpieczonych w Kasie Rolniczego Ubezpieczenia Społecznego}

1. Zasiłek opiekuńczy w powszechnym systemie ubezpieczenia społecznego pierwszy raz został unormowany już w latach 30 . XX wieku ${ }^{1}$. Instytucję tę ustawodawca ukształtował wówczas w granicach ochrony ryzyka niezdolności do pracy z powodu choroby. Ustanowione w późniejszych latach akty prawne wyodrębniły wyraźnie to świadczenie w ubezpieczeniu społecznym ${ }^{2}$, określiły przesłanki jego przysługiwania ${ }^{3}$ oraz rozszerzyły katalog podmiotów uprawnionych do zasiłku opiekuńczego ${ }^{4}$. Szczególna sytuacja, jaką był wybuch pandemii w 2020 r., spowodowała dostosowanie obowiązujących rozwiązań prawnych do potrzeb osób pracujących w gospodarstwach rolnych i ubezpieczonych w Kasie Rolniczego Ubezpieczenia Społecznego (KRUS). Wprowadzenie nowej instytucji pomocy dla rolników stało się powodem podjęcia niniejszych badań.

* Uniwersytet Przyrodniczy w Poznaniu.

${ }^{1}$ Ustawa z 28 marca 1933 r. o ubezpieczeniu społecznym (Dz. U. Nr 51, poz. 396).

${ }^{2}$ Ustawa z 17 grudnia 1974 r. o świadczeniach pieniężnych w razie choroby i macierzyństwa (Dz. U. Nr 47, poz. 280).

${ }^{3}$ Chodzi zwłaszcza o rozwiązania wprowadzone ustawą z 25 czerwca 1999 r. o świadczeniach pieniężnych z ubezpieczenia społecznego w razie choroby i macierzyństwa (Dz. U. Nr 60, poz. $636 \mathrm{z}$ późn. zm.).

${ }^{4}$ Poza pracownikami zasiłek opiekuńczy przyznany został także innym osobom podlegającym ubezpieczeniu chorobowemu w Zakładzie Ubezpieczeń Społecznych (ZUS). 
Celem rozważań jest odpowiedź na pytanie, na ile przejęta z powszechnego ubezpieczenia społecznego swoista konstrukcja prawa do zasiłku opiekuńczego zapewnia ochronę podmiotom prowadzącym działalność rolniczą. Realizując ten cel, należy przedstawić ogólną charakterystykę zasiłku opiekuńczego przewidzianego dla podmiotów ubezpieczonych w ZUS, a następnie określić istotę i funkcje nowego świadczenia przysługującego rolnikom. Zagadnieniami wymagającymi rozstrzygnięcia będą: zasady przyznawania świadczenia, określenie podstaw jego wymiaru, wskazanie okresów przysługiwania zasiłku oraz ustalenie przesłanek pozbawiających prawa do świadczeń. Szczególną uwagę należy zwrócić na problemy finansowania zasiłków opiekuńczych i kwestie wysokości świadczeń uzyskiwanych przez podmioty uprawnione. Warto również zastanowić się nad celowością niedawno wprowadzonych rozwiązań prawnych.

2. Obecna konstrukcja prawa do zasiłku opiekuńczego została określona w kilku aktach prawnych. Podstawę unormowania stanowi ustawa z 25 czerwca 1999 r. o świadczeniach pieniężnych z ubezpieczenia społecznego $\mathrm{w}$ razie choroby i macierzyństwa ${ }^{5}$. Kwestie te reguluje także specjalny akt prawny - ustawa z 2 marca 2020 r. o szczególnych rozwiązaniach związanych z zapobieganiem, przeciwdziałaniem i zwalczaniem COVID-19, innych chorób zakaźnych oraz wywołanych nimi sytuacji kryzysowych ${ }^{6}$ wraz z rozporządzeniami Rady Ministrów w sprawie określenia dłuższego okresu pobierania zasiłku opiekuńczego w celu przeciwdziałania COVID-197.

Zgodnie z art. 32 ustawy o świadczeniach pieniężnych z ubezpieczenia społecznego $\mathrm{w}$ razie choroby i macierzyństwa zasiłek opiekuńczy z powszechnego ubezpieczenia społecznego przysługuje ubezpieczonemu zwolnionemu z wykonywania pracy z powodu osobistego sprawowania opieki nad dzieckiem zdrowym do ukończenia 8. roku życia oraz dzieckiem przebywającym w szpitalu bądź innym zakładzie leczniczym. Prawo do zasiłku na dziecko zdrowe przysługuje w razie zamknięcia żłobka, przedszkola, klubu dziecięcego albo szkoły, gdzie uczęszcza dziecko, jeśli do zamknięcia

${ }^{5}$ Ustawa z 25 czerwca 1999 r. o świadczeniach pieniężnych z ubezpieczenia społecznego w razie choroby i macierzyństwa (t.j. Dz. U. z 2020 r., poz. 870 ze zm.).

${ }^{6}$ Ustawa z 2 marca 2020 r. o szczególnych rozwiązaniach związanych z zapobieganiem, przeciwdziałaniem i zwalczaniem COVID-19, innych chorób zakaźnych oraz wywołanych nimi sytuacji kryzysowych (Dz. U. poz. 1842 ze zm.).

7 Rozporządzenie Rady Ministrów z 30 kwietnia 2020 r. w sprawie określenia dłuższego okresu pobierania zasiłku opiekuńczego w celu przeciwdziałania COVID-19 (Dz. U. poz. 790) i następne wydawane co miesiąc oraz rozporządzenie Rady Ministrów z 12 marca 2021 r. w sprawie określenia dłuższego okresu pobierania zasiłku opiekuńczego w celu przeciwdziałania COVID-19 (Dz. U. poz. 455). 
doszło w sposób nieprzewidziany, a powiadomienie o zaistniałej sytuacji nastąpiło w terminie krótszym niż 7 dni. Ze świadczenia można skorzystać także w razie choroby niani, z którą została zawarta umowa uaktywniająca, bądź opiekuna dziennego, któremu zostało powierzone dziecko pod opiekę ${ }^{8}$, oraz w okresie porodu albo choroby małżonka ubezpieczonego bądź rodzica dziecka, którzy opiekują się dzieckiem, jeżeli wspomniane przyczyny stanowią przeszkodę w sprawowaniu opieki przez tego małżonka albo rodzica.

Według art. 32 ust. 3 tej ustawy zasiłek opiekuńczy może przysługiwać także z powodu sprawowania opieki nad dzieckiem chorym do ukończenia przez nie 14. roku życia oraz innym chorym członkiem rodziny: małżonkiem, rodzicami, rodzicem dziecka, ojczymem, macochą, dziadkami, teściami, rodzeństwem, wnukami oraz dziećmi mającymi powyżej 14 lat - jeżeli osoby te $\mathrm{w}$ okresie sprawowania opieki przebywają wraz z ubezpieczonym we wspólnym gospodarstwie domowym. Za dzieci ustawodawca uważa dzieci własne ubezpieczonego lub jego małżonka oraz dzieci przysposobione, a także dzieci przyjęte na wychowanie i utrzymanie.

Przepisy dotyczące zasiłków chorobowych stosuje się odpowiednio do zasiłku opiekuńczego w kwestii należności zasiłku za każdy dzień kalendarzowy, braku uprawnienia do zasiłku, jeżeli pracownik dysponuje prawem do wynagrodzenia w czasie opieki, pozbawienia prawa do świadczenia, gdy wykorzystuje się zwolnienie od obowiązku świadczenia pracy dla innych niż opieka celów w okresie jej sprawowania9. O prawo do zasiłku nie można ubiegać się w okresie urlopu bezpłatnego, wychowawczego, odbywania kary pozbawienia wolności bądź tymczasowego aresztu (z wyjątkiem wykonywania pracy za opłatą na podstawie skierowania).

Zasiłek opiekuńczy przysługuje pracownikom przez okres nieprzekraczający 60 dni w ciągu roku kalendarzowego, jeżeli konieczna jest opieka nad dzieckiem do 8 lat, które jest zdrowe, bądź chorym dzieckiem do lat 14 . W przypadku obowiązku sprawowania opieki nad innym członkiem rodziny (w tym dzieckiem powyżej 14 lat) świadczenie to może przysługiwać przez okres nie dłuższy niż 14 dni w roku kalendarzowym. Jest to łączny wymiar (nie może on przekraczać 60 dni w roku kalendarzowym) dla matki i ojca dziecka, bez względu na liczbę dzieci i innych chorych członków rodziny.

Wskazane okresy zasiłkowe są zatem niezależne od liczby dzieci i innych członków rodziny, ale nie są niezależne od siebie. Oznacza to, że okresy opieki się sumuje. Sumowania dokonuje się w ramach roku kalendarzowego

${ }^{8}$ Ustawa z 4 lutego 2011 r. o opiece nad dziećmi w wieku do lat 3 (Dz. U. z 2016 r., poz. 157).

9 Z. Kluszczyńska, W. Koczur, K. Roszewska, K. Rubel, G. Szpor, T. Szumilcz, System ubezpieczeń spotecznych. Zagadnienia podstawowe, Warszawa 2016, s. 119. 
i okresu 60-dniowego. Limit niewykorzystany w danym roku nie przechodzi na następny rok $^{10}$.

Dodatkowy zasiłek opiekuńczy z powodu zamknięcia placówki szkolnej czy wychowawczej nie wlicza się jednak do wskazanego wyżej limitu 60 dni w roku kalendarzowym. Po wejściu w życie przepisów ustawy nowelizującej ustawę z 2 marca 2020 r. o szczególnych rozwiązaniach związanych z zapobieganiem, przeciwdziałaniem i zwalczaniem COVID-19, innych chorób zakaźnych oraz wywołanych nimi sytuacji kryzysowych ${ }^{11}$ z mocą wsteczną od 26 marca 2020 r. wniosek złożony przez pracownika o zasiłek opiekuńczy został przekształcony we wniosek o dodatkowy zasiłek opiekuńczy. W ten sposób ustanowiony został przede wszystkim dla pracowników, w ramach ubezpieczenia chorobowego w ZUS, szczególny, dodatkowy zasiłek opiekuńczy. Podstawowy okres jego przysługiwania został określony ustawowo na 14 dni z możliwością przedłużenia go rozporządzeniem Prezesa Rady Ministrów.

Prawo do zasiłku opiekuńczego nie przysługuje, jeśli istnieje możliwość zapewnienia dziecku opieki. Przesłanka ta zachodzi wtedy, gdy we wspólnym gospodarstwie domowym $\mathrm{z}$ ubezpieczonym pozostają inni członkowie rodziny, którzy mają możliwość sprawowania opieki nad dzieckiem albo chorym członkiem należącym do rodziny ( $\mathrm{z}$ wyłączeniem sprawowania opieki nad dzieckiem do lat 2) ${ }^{12}$.

Zasiłek opiekuńczy z ubezpieczenia powszechnego określa się w wysokości $80 \%$ podstawy wymiaru. Wypłaca się go w 1/30 części za każdy dzień sprawowania opieki. Podstawą wymiaru zasiłku jest przeciętne miesięczne wynagrodzenie, które pracownik otrzymał za okres 12 miesięcy kalendarzowych poprzedzających miesiąc, w którym zaistniała podstawa do zwolnienia od świadczenia pracy ${ }^{13}$. Zasiłek opiekuńczy przysługuje za każdy dzień niezdolności do pracy, nie wyłączając dni wolnych od pracy ${ }^{14}$. Wniosek należy złożyć w ZUS na formularzu Z-15A ${ }^{15}$.

${ }^{10}$ I. Jędrasik-Jankowska, Pojęcie i konstrukcje prawne ubezpieczenia społecznego, Warszawa 2014, s. 390.

${ }^{11}$ Ustawa z 2 marca 2020 r. o szczególnych rozwiązaniach związanych z zapobieganiem, przeciwdziałaniem i zwalczaniem COVID-19, innych chorób zakaźnych oraz wywołanych nimi sytuacji kryzysowych (Dz. U. poz. 1842 ze zm.).

${ }_{12}$ E. Dziubińska-Lechnio, M. Kostrzewa, J. Kaleta, Meritum. Ubezpieczenia społeczne 2017, Warszawa 2017, s. 423.

${ }_{13}$ Z. Kluszczyńska, W. Koczur, K. Roszewska, K. Rubel, G. Szpor, T. Szumilcz, System ubezpieczeń społecznych..., s. 118 i n.

${ }^{14}$ I. Jędrasik-Jankowska, Pojęcie i konstrukcje prawne..., s. 392.

15 Dotyczy to wniosku o zasiłek opiekuńczy na dziecko zdrowe, natomiast w przypadku opieki nad innym niż dziecko członkiem rodziny wniosek składa się na formularzu Z-15B. 
Aby skorzystać z prawa do dodatkowego zasiłku opiekuńczego, należy złożyć u pracodawcy lub zleceniodawcy oświadczenie o sprawowaniu opieki nad dzieckiem. Oświadczenie to ma charakter wniosku o dodatkowy zasiłek opiekuńczy. Zasady naliczania wymiaru dodatkowego zasiłku opiekuńczego dla pracowników są analogiczne, jak te stosowane przy ustalaniu podstawy wymiaru zasiłku opiekuńczego i zasiłku chorobowego. Mając na względzie aktualną kwotę minimalnego wynagrodzenia ${ }^{16}$, świadczenie to w $2021 \mathrm{r}$. wyniesie w wymiarze podstawowym 74,67 zł za dzień niezdolności do pracy.

3. Rolnicze ubezpieczenie społeczne nie obejmuje rolników i domowników ochroną na wypadek utraty zdolności do pracy spowodowanej koniecznością sprawowania osobistej opieki nad dzieckiem. Instytucja prawa do rolniczego zasiłku opiekuńczego została bowiem skonstruowana poza tym systemem. Możliwość ubiegania się o wskazane świadczenie mają jednak tylko podmioty ubezpieczone w KRUS. Rozwiązania dotyczące przyznawania zasiłków dla rolników zostały w ograniczonym zakresie przejęte z powszechnego systemu ubezpieczenia społecznego, przy zaangażowaniu środków publicznych. Warto wspomnieć, że to swoiste rozwiązanie zostało wprowadzone w sytuacji szczególnej - zagrożenia zakażeniem COVID-19.

Dnia 31 marca 2020 r. weszła w życie ustawa o zmianie ustawy o szczególnych rozwiązaniach związanych z zapobieganiem, przeciwdziałaniem i zwalczaniem COVID-19, innych chorób zakaźnych oraz wywołanych nimi sytuacji kryzysowych oraz niektórych innych ustaw ${ }^{17}$. Powyższy akt prawny wprowadził szereg zmian w ,specustawie” z 2 marca 2020 r., w tym rozwiązania przewidujące pomoc finansową z budżetu państwa dla środowiska rolniczego.

Zgodnie z art. 1 pkt 4 wspomnianego wyżej aktu prawnego wprowadzono dla podmiotów objętych ubezpieczeniem społecznym rolników możliwość uzyskania prawa do zasiłku opiekuńczego. Do procedury przyznawania i wypłaty zasiłku opiekuńczego zastosowanie tu mają przepisy ustawy o świadczeniach pieniężnych z ubezpieczenia społecznego w razie choroby i macierzyństwa.

Prawo do świadczenia przyznane zostało osobie podlegającej rolniczemu ubezpieczeniu społecznemu: wypadkowemu, chorobowemu i macierzyńskie-

16 Zgodnie z rozporządzeniem Rady Ministrów z 15 września 2020 r. w sprawie wysokości minimalnego wynagrodzenia za pracę oraz wysokości minimalnej stawki godzinowej w $2021 \mathrm{r}$. wynosi ono 2800 zł brutto (Dz. U. poz. 1596).

17 Ustawa z 31 marca 2020 r. o zmianie ustawy o szczególnych rozwiązaniach związanych z zapobieganiem, przeciwdziałaniem i zwalczaniem COVID-19, innych chorób zakaźnych oraz wywołanych nimi sytuacji kryzysowych oraz niektórych innych ustaw (Dz. U. poz. 568). 
mu oraz osobie podlegającej ubezpieczeniu emerytalno-rentowemu. Katalog podmiotowy obejmuje zatem zarówno rolnika, jak i jego małżonka oraz domownika podlegającego we wskazanym wyżej zakresie ubezpieczeniu w KRUS. Warto zauważyć, że zasiłek opiekuńczy przysługuje niezależnie od okresu podlegania ubezpieczeniu społecznemu rolników. Nie jest tu także wymagany nieprzerwany 12 -miesięczny okres ubezpieczenia w przypadku przystąpienia do ubezpieczenia na wniosek.

Powodem przyznania zasiłku opiekuńczego jest powstanie przeszkody w wykonywaniu pracy rolniczej, spowodowanej koniecznością zaopiekowania się dzieckiem, które nie może uczęszczać do żłobka, klubu dziecięcego, przedszkola, szkoły lub innej placówki w wyniku jej zamknięcia na skutek zagrożenia zakażeniem COVID-19. Zasiłek ten przysługuje także z powodu niemożności sprawowania opieki przez nianię lub dziennego opiekuna z powodu COVID-19.

Świadczenie przysługuje uprawnionemu z powodu konieczności osobistego sprawowania opieki nad dzieckiem do 8 lat, posiadającym orzeczenie o znacznym lub umiarkowanym stopniu niepełnosprawności do ukończenia 18 lat oraz posiadającym orzeczenie o niepełnosprawności lub orzeczenie o potrzebie kształcenia specjalnego. Chodzi tu o opiekę nad dziećmi własnymi ubezpieczonego lub jego małżonka oraz dziećmi przysposobionymi, a także przyjętymi na wychowanie i utrzymanie (np. w ramach rodziny zastępczej niezawodowej).

Warto zauważyć, że w przypadku dzieci poniżej 8 lat prawo do zasiłku opiekuńczego przysługuje nie dłużej niż do dnia poprzedzającego ósme urodziny dziecka. Analogiczna zasada dotyczy dzieci, które kończą 18 lat. Uwaga ta jest o tyle istotna, że pomimo zamknięcia szkoły podstawowej w klasie pierwszej mogą znajdować się dzieci kończące 8 lat już z dniem 1 stycznia 2021 r., w którym ustawowo prawo do świadczenia ustanie.

Zasiłek opiekuńczy z tytułu opieki nad dzieckiem przysługuje na równi matce i ojcu dziecka (lub opiekunowi prawnemu). Wypłaca się go jednak tylko jednemu z rodziców, który wystąpi z wnioskiem o świadczenie za dany okres. Zasiłek przyznawany jest w równej wysokości, niezależnie od liczby dzieci, które wymagają opieki.

Prawo do świadczenia nie przysługuje, jeżeli drugi z rodziców dziecka może zapewnić dziecku opiekę, np. jest bezrobotny, korzysta z urlopu rodzicielskiego czy urlopu wychowawczego. Zasada ta rozciąga się także na sytuację, gdy poza ubezpieczonym są też inni członkowie rodziny pozostający we wspólnym gospodarstwie domowym, którzy mogą zapewnić opiekę dziecku. W katalogu takich podmiotów nie można jednak uwzględnić osoby, która jest całkowicie niezdolna do pracy, jest chora, niesprawna fizycznie lub 
psychicznie ze względu na swój wiek, nie jest zobowiązana do sprawowania opieki na podstawie kodeksu rodzinnego i opiekuńczego lub odmawia sprawowania opieki. Podmiotem zastępującym rolnika lub domownika w opiece nad dzieckiem nie może być także osoba, która prowadzi gospodarstwo rolne lub działalność pozarolniczą.

Prawo do zasiłku nie przysługuje też ubezpieczonemu, pomimo spełnienia wymaganych przesłanek ustawowych, jeżeli w okresie wystąpienia wymaganej przeszkody pobiera on zasiłek chorobowy w związku z czasową niezdolnością do pracy w gospodarstwie rolnym lub zasiłek macierzyński. Przeszkodą w uzyskaniu zasiłku jest przebywanie wnioskodawcy w areszcie tymczasowym lub odbywania kary pozbawienia wolności w okresie pobierania świadczenia. Nie można także zapomnieć, że w przypadku, gdy ubezpieczony wykorzystał okres opieki w sposób niezgodny $\mathrm{z}$ celem tej opieki, traci on prawo do zasiłku opiekuńczego za cały okres. Wypłatę zasiłku opiekuńczego wstrzymuje się, jeżeli prawo do zasiłku ustało albo okaże się, że prawo takie w ogóle nie istniało.

Ze względu na wprowadzone w kraju obostrzenia procedura uzyskania zasiłku przybrała formę szczególną. Pisemny wniosek ${ }^{18}$ można bowiem składać za pośrednictwem przedsiębiorcy uprawnionego do wykonywania działalności pocztowej w obrocie krajowym lub zagranicznym, przez elektroniczną skrzynkę podawczą KRUS - ePUAP, w formie dokumentu elektronicznego podpisanego kwalifikowanym podpisem elektronicznym czy podpisem zaufanym oraz osobiście (wniosek wydrukowany, uzupełniony, podpisany i dostarczony za pomocą przygotowanych wrzutni w placówkach KRUS).

Poprawne złożenie wniosku jest podstawą do wszczęcia postępowania w sprawie przyznania i wypłaty świadczenia. Zasiłek opiekuńczy z tytułu opieki nad dzieckiem, po zweryfikowaniu przesłanek formalnych, wypłacany jest niezwłocznie, nie później niż w ciągu 30 dni od daty złożenia dokumentów niezbędnych do stwierdzenia uprawnień. Wypłata świadczenia przez KRUS następuje na wskazany we wniosku rachunek bankowy, ewentualnie na podany adres zamieszkania lub korespondencji, zgodnie $\mathrm{z}$ intencją wnioskodawcy.

Należy wspomnieć, że uprawniony, któremu przyznano świadczenie, został zobowiązany do niezwłocznego informowania KRUS o wszelkich

\footnotetext{
${ }^{18}$ Niejednokrotnie postępowanie o świadczenie wymaga przedłożenia dodatkowych załączników do wniosku. Koniecznie jest to w przypadku sprawowania opieki nad dzieckiem niepełnosprawnym. Chodzi tu o dokumenty, które potwierdzają niepełnosprawność, np. orzeczenia o niepełnosprawności, znacznym stopniu niepełnosprawności, umiarkowanym stopniu niepełnosprawności czy o potrzebie kształcenia specjalnego.
} 
zmianach mających wpływ na prawo do tego świadczenia oraz jego wysokość. Chodzi tu w szczególności o tymczasowe aresztowanie lub odbywanie kary pozbawienia wolności w okresie otrzymywania zasiłku opiekuńczego, przyznanie prawa do emerytury, renty z innego organu rentowego, podjęcie zatrudnienia lub innej działalności podlegającej ubezpieczeniom społecznym, przyznanie zasiłku opiekuńczego przez inny organ lub pracodawcę osobie, która może zapewnić opiekę. Nie można także zapomnieć, że rolnik, który pobrał nienależnie zasiłek opiekuńczy, jest zobowiązany do jego zwrotu, łącznie z odsetkami ustawowymi, za opóźnienie w wysokości i na zasadach określonych przepisami prawa cywilnego.

Jak wyżej podkreślono, rolniczy zasiłek opiekuńczy jest rozwiązaniem szczególnym, wprowadzonym w wyjątkowym czasie pandemii. Z uwagi na przesłanki jego ukonstytuowania można go nazwać „,covidowym rolniczym zasiłkiem opiekuńczym". W pierwotnej wersji, analogicznie jak w ubezpieczeniu powszechnym, świadczenie dla rolników miało przysługiwać na okres 14 dni. Ze względu na przedłużający się stan zagrożenia zakażeniem COVID-19 okres przysługiwania zasiłku został kilkakrotnie przedłużony rozporządzeniem Prezesa Rady Ministrów ${ }^{19}$.

Ustawodawca uznał, że kwota rolniczego zasiłku opiekuńczego za każdy kalendarzowy dzień opieki wyniesie 32,41 zł, co stanowi 1/30 kwoty emerytury podstawowej, która od 1 marca 2020 r. wynosiła 972,40 zł². Mimo że obsługę związaną z procedurą przyznania i wypłaty świadczeń powierzono KRUS, zasiłek opiekuńczy dla rolników finansowany jest w całości z budżetu państwa. Jego kwota nie jest zatem uzależniona od składek odprowadzanych na ubezpieczenie chorobowe czy od dochodów uzyskiwanych z gospodarstwa rolnego. Jest kwotą stałą dla wszystkich rolników, a podstawę przyznania prawa do świadczenia stanowi jedynie podleganie wnioskodawcy rolniczemu ubezpieczeniu społecznemu.

Analogicznie jak w przypadku pracowników, ustawodawca przewidział możliwość przedłużenia okresu pobierania zasiłku, jednak nie dłużej niż do ukończenia przez dziecko 8 lat. Warto podkreślić, że w pierwotnej formie ubezpieczonemu rolnikowi mogło za cały 14-dniowy okres zasiłkowy przysługiwać świadczenie w wysokości 453,74 zł. Porównując tę

19 Rada Ministrów może, w celu przeciwdziałania COVID-19, w drodze rozporządzenia określić dłuższy okres pobierania dodatkowego zasiłku opiekuńczego. Obecnie okres ten został przedłużony do 28 marca - rozporządzenie Rady Ministrów z 12 marca 2021 r. w sprawie określenia dłuższego okresu pobierania zasiłku opiekuńczego w celu przeciwdziałania COVID-19 (Dz. U. poz. 456).

20 Od 1 marca $2021 \mathrm{r}$. kwota podstawowej emerytury rolniczej wynosi 1013,63 zł-komunikat Prezesa KRUS z 15 lutego 2020 r., www.krus.gov.pl. 
kwotę z podstawowym, powszechnym zasiłkiem przysługującym w $2020 \mathrm{r}$. pracownikom, można tu zauważyć poważną dysproporcję. Świadczenie to za 14-dniowy analogiczny okres wynosiło bowiem dla pracownika co najmniej 970,62 zł, co daje kwotę 69,33 zł za każdy dzień niezdolności do pracy. Podstawę wymiaru zasiłku w tej kategorii podmiotów uprawnionych stanowi najniższe miesięczne wynagrodzenie uzyskiwane w okresie ostatnich 12 miesięcy.

W porównaniu do rolnika pracownik w ramach dodatkowego zasiłku opiekuńczego otrzymywał ponad $100 \%$ wyższe świadczenie za każdy dzień opieki nad dzieckiem. Nie można przy tym zapominać, że pracownikowi świadczenie to przysługuje $\mathrm{z}$ większej liczby podstaw i na dłuższy okres $\mathrm{z}$ uwagi na posiadane prawo do ,podstawowego" zasiłku opiekuńczego. W przypadku pracowników zasiłki opiekuńcze zależą jednak od wysokości uzyskiwanego wynagrodzenia, zostały bowiem skonstruowane w ramach ubezpieczenia społecznego i są powiązane $\mathrm{z}$ opłacaniem składek na ubezpieczenie chorobowe oraz w całości finansowane z Funduszu Ubezpieczeń Społecznych.

4. Podstawą funkcjonowania zasiłku opiekuńczego w systemie powszechnego ubezpieczenia społecznego jest potrzeba ochrony przed utratą dochodów z tytułu określonych ustawowo zdarzeń, które stanowią przeszkodę w wykonywaniu pracy. Charakter tej przeszkody różni się znacznie od konstrukcji przyjętej w ubezpieczeniu chorobowym. Chodzi tu bowiem o pomoc osobom zdolnym do pracy, ale rezygnującym z niej po to, aby opiekować się członkiem rodziny. Przeszkodę tę w pierwszej kolejności stanowi opieka nad chorym dzieckiem do lat 14. Ochrona ta została przez ustawodawcę rozciągnięta na innych członków rodziny. W szczególnych sytuacjach obejmuje także zdrowe dzieci do 8 lat. Konstrukcja ta wynika zatem z realizacji ochronnej funkcji ubezpieczeń społecznych.

Zasiłek opiekuńczy w systemie powszechnym jest świadczeniem pieniężnym wypłacanym z ubezpieczenia chorobowego osobom ubezpieczonym bez względu na to, czy podlegają ubezpieczeniu obowiązkowo, czy dobrowolnie. Zasiłek w tym systemie ubezpieczeń społecznych oparty jest na zasadzie samofinansowania, a prawo do niego przysługuje bez okresu wyczekiwania (już od pierwszego dnia objęcia ubezpieczeniem chorobowym). Zasiłek przysługuje uprawnionemu za czas zwolnienia od świadczenia pracy w przypadku konieczności sprawowania osobistej opieki nad dzieckiem ${ }^{21}$.

${ }^{21}$ P. Biernat, E. Gronek, Zasitek macierzyński oraz zasitek opiekuńczy jako świadczenia pieniężne wyptacane z ubezpieczeń społecznych $w$ ramach ubezpieczenia chorobowego, „Rynek - Społeczeństwo - Kultura” 2018 nr 2(28), s. 39-43. 
Dopiero wystąpienie nadzwyczajnej sytuacji w Polsce - pandemii COVID-19 - pokazało, że rolnicy pozbawieni są ochrony na wypadek utraty zdolności do zarobkowania z powodu konieczności sprawowania osobistej opieki nad zdrowym dzieckiem. Ustawodawca zdecydował się na wsparcie rolników poprzez objęcie ich ochroną za pomocą instytucji zasiłków opiekuńczych. Zasiłek opiekuńczy przysługuje dziś rolnikom ubezpieczonym w KRUS jedynie w kontekście COVID-1922.

Niełatwo jest uargumentować przesłanki uzasadniające wprowadzenie analizowanej konstrukcji prawa do zasiłku opiekuńczego dla rolników. Również ustawodawca się na to nie odważył, poza stwierdzeniem, że wprowadzona regulacja stanowi pomoc budżetu państwa dla środowiska rolniczego w okolicznościach wprowadzenia w kraju stanu epidemii w związku z COVID-1923. Legislator wskazał też, że rolnicy takiej ochrony dotychczas nie mieli i że niemożliwe jest podanie danych innych niż szacunkowe w zakresie przewidywanej liczby osób objętych takim zasiłkiem. Z uwagi na brak środków na wypłatę zasiłków w KRUS konieczne było sfinansowanie świadczeń $\mathrm{z}$ budżetu państwa ${ }^{24}$.

Warto się zatem zastanowić, dlaczego podmiotom objętym społecznym ubezpieczeniem rolników nie przysługiwało dotychczas analizowane świadczenie. Być może wcześniej ustawodawca zakładał, że z uwagi na wielopokoleniowość rodzin żyjących w gospodarstwach rolnych i związaną z nią możliwość znalezienia opieki dla dziecka nie było dotąd potrzeby przyjęcia tej instytucji na wzór uprawnień pracowników ubezpieczonych w ZUS. Argumentacja ta, po uwzględnieniu aktualnej regulacji, jest nadal aktualna, gdyż w przypadku istnienia możliwości zorganizowania opieki dla dziecka prawo do rolniczego zasiłku opiekuńczego nie powstanie.

Instytucja zasiłku opiekuńczego nabiera szczególnego znaczenia w małych, niewielopokoleniowych gospodarstwach rodzinnych. Trzeba bowiem zauważyć, że w działalności rolniczej istnieje potrzeba stałego podtrzymywania produkcji, co jest szczególnie widoczne przy zwierzęcym profilu produkcji. Zapewnienie opieki dziecku do 8. roku życia może zatem stanowić realną przeszkodę w wykonywaniu pracy rolniczej. Nie pozostaje to

${ }^{22} \mathrm{~K}$. Szmid, Ustawa o szczególnych rozwiazaniach zwiąanych z zapobieganiem, przeciwdziałaniem i zwalczaniem COVID-19, innych chorób zakaźnych oraz wywołanych nimi sytuacji kryzysowych. Komentarz, Warszawa 2020, Legalis.

${ }^{23}$ Uzasadnienie do projektu ustawy o szczególnych rozwiązaniach związanych z zapobieganiem, przeciwdziałaniem i zwalczaniem COVID-19, innych chorób zakaźnych oraz wywołanych nimi sytuacji kryzysowych, druk sejmowy nr 299, s. 3, www.sejm.gov.pl.

${ }^{24}$ Ibidem. 
bez wpływu na dostępne zasoby pracy w gospodarstwie i uzyskiwane przez rolników dochody.

Produkcja rolnicza różni się znacznie od innych działalności zawodowych. Pracę w rolnictwie cechuje brak ram czasowych oraz zmienność warunków jej wykonywania, wielozadaniowość, sezonowość i konieczność częstego korzystania z pomocy osób najbliższych ${ }^{25}$. Działalność rolnicza niejednokrotnie wymaga od producenta rolnego wykonywania rozmaitych czynności poza terenem gospodarstwa. Jednocześnie charakteryzuje ją niezwykle silny związek z gospodarstwem domowym.

Nie można zapominać, że na małe dziecko pozbawione opieki na terenie gospodarstwa czyha wiele zagrożeń. Według danych publikowanych przez International Social Security Association (ISSA) ${ }^{26} 2 / 3$ dzieci, które giną w europejskich gospodarstwach rolnych, ma poniżej 5 lat, a najczęstszą przyczyną ich śmierci są zdarzenia z udziałem pojazdów. Wśród innych przyczyn wypadków śmiertelnych ISSA wskazuje: maszyny, utonięcia, uduszenia, kontakt ze zwierzętami. Wysoki wskaźnik wypadków śmiertelnych to zatem efekt: niezrozumienia zagrożenia przez rolników, rodziców i dzieci, niewłaściwego szkolenia i nadzoru oraz niewłaściwego zabezpieczenia miejsca zabaw ${ }^{27}$. Zagadnienie ochrony dzieci w rolnictwie było wielokrotnie poruszane w doktrynie. Publikacje te ${ }^{28}$ dotyczą szeroko rozumianego bezpieczeństwa dzieci w gospodarstwach rolnych. Wspomniane problemy nie pozostają bez znaczenia dla kwestii dopuszczalności pracy tak małych dzieci w rolnictwie w związku z potrzebą zapewnienia im należytej ochrony przed

${ }^{25}$ Szerzej: D. Puślecki, Z problematyki prawnej wypadku przy pracy rolniczej, „Prawo i Administracja" 2006, t. V, s. 325 i n.

${ }^{26}$ Organizacja powstała w 1927 r. z siedzibą w Genewie w Szwajcarii. Jest to największa na świecie międzynarodowa organizacja skupiająca instytucje zabezpieczenia społecznego www. issa.int. KRUS jest członkiem ISSA od 1992 r. Dane na podstawie: European Commission, Protecting health and safety of workers in agriculture, livestock farming, horticulture and forestry, Luxembourg 2012, s. 51.

${ }^{27}$ Szerzej: M.A. Król, Rozwiąania prawne w zakresie zabezpieczenia warunków pracy kobiet i przeciwdziałania wypadkom z udziałem dzieci $w$ rolnictwie w aktach międzynarodowych $i$ wybranych państwach europejskich, „Ubezpieczenia w Rolnictwie. Materiały i Studia” 2015, nr 53, s. 85-86.

${ }_{28}$ M. Skąpski, Wybrane zagadnienia współpracy zawodowej rodziców i dzieci, „Ubezpieczenia w Rolnictwie. Materiały i Studia” 1999, nr 4, s. 42 i n.; S. Lachowski, Uregulowania prawne możliwości angażowania dzieci do pracy w rodzinnym gospodarstwie rolnym, w: J. Zagórski, S. Lachowski, Zagrożenia zdrowia dzieci angażowanych do prac $w$ rodzinnym gospodarstwie rolnym, Lublin 1999, s. 24 i n.; M.A. Król, Rozwiazania prawne ..., s. 91-99, D. Puślecki, Prawna ochrona dzieci pracujących $w$ rodzinnym gospodarstwie rolnym na tle rozwiąań przyjętych $w$ wybranym ustawodawstwie europejskim, w: A. Stelmach i in., Stosunki międzynarodowe w procesie zmian, Poznań 2018, s. 441 i n. 
wypadkami przy pracy ${ }^{29}$. Z tego względu sprawa wprowadzenia zasiłku opiekuńczego dla rolników nabiera szczególnego charakteru.

Podczas wykonywania pracy rolniczej nie można tak małych dzieci pozostawiać bez opieki. Jednak zaangażowanie ich w czasie zamknięcia placówek szkolnych i wychowawczych do pomocy przy pracy w rolnictwie budzi poważne wątpliwości. Z uwagi na silny związek gospodarstwa rolnego i domowego oraz zagrożenia związane $\mathrm{z}$ wykonywaniem nawet najprostszych czynności w działalności rolniczej nie wydaje się dziś słuszne szerokie rozumienie zobowiązania dzieci wiejskich do pomocy rodzicom we wspólnym gospodarstwie. Trzeba bowiem pamiętać, że dotyczy to dzieci niepełnoletnich (do 8. roku życia), a więc także tych objętych już obowiązkiem edukacyjnym ${ }^{30}$.

5. Podstawą funkcjonowania instytucji prawa do rolniczego zasiłku opiekuńczego jest potrzeba zapewnienia rolnikom ochrony w sytuacji nadzwyczajnej, jaką stanowi zamknięcie placówek wychowawczych i szkolnych dla dzieci wiejskich na skutek pandemii. W przypadku środowiska wiejskiego ochrona ta powinna być rozważana szerzej niż w powszechnym ubezpieczeniu społecznym. Ochrona ta dotyczy bowiem nie tylko rodziców, ze względu na sytuację zagrażającą pozyskiwaniu przez nich dochodów, lecz także dzieci, które mogłyby zostać pozbawione opieki na często niebezpiecznym terenie gospodarstwa rolnego. Instytucja rolniczego zasiłku opiekuńczego powinna również zachęcać rodzica do zaprzestania wykonywania pracy rolniczej na rzecz opieki nad dzieckiem z powodu zamknięcia placówek szkolnych i wychowawczych.

Realizacja funkcji gwarancyjnej świadczenia nie budzi wątpliwości. Świadczenia zasiłkowe zostały całkowicie sfinansowane z budżetu państwa. Wypłata przyznanych w postępowaniu wnioskowym i tak sfinansowanych świadczeń została jedynie zrealizowana za pomocą obsługi KRUS. Jednak prawo do zasiłku opiekuńczego zostało przyznane w aktualnej regulacji prawnej tylko podmiotom objętym rolniczym ubezpieczeniem społecznym. Przyjęcie takiego modelu finansowania zasiłków pozwala stwierdzić, że wypłata świadczeń dla rolników została w tym przypadku w pełni zagwarantowana przez państwo.

Najwięcej kontrowersji budzi jednak charakter kompensacyjny analizowanego świadczenia. Można nawet powiedzieć, że funkcja kompensacyjna jest w tym przypadku dyskusyjna. Podstawowym problemem jest tu wysokość określonego ustawowo świadczenia opiekuńczego dla rolników ubezpieczo-

${ }^{29}$ D. Puślecki, Ubezpieczenie od następstw nieszczęśliwych wypadków i chorób dla dzieci rolników ubezpieczonych w KRUS, „Przegląd Prawa Rolnego” 2020, nr 1, s. 141 i n.

${ }^{30}$ Dzieci uczęszczających do pierwszej klasy szkoły podstawowej i klasy zerowej w placówkach przedszkolnych i szkolnych. 
nych w KRUS, tj. 32,41 zł dziennie ${ }^{31}$. W porównaniu do analogicznej sytuacji osób podlegających powszechnemu systemowi ubezpieczenia społecznego i otrzymujących minimalne wynagrodzenie świadczenie to jest o połowę niższe.

Z ekonomicznego punktu widzenia kwota zasiłku opiekuńczego jest jednak korzystniejsza dla rolnika niż uzyskiwane obecnie świadczenia z ubezpieczenia chorobowego w wysokości 10 zł za każdy dzień niezdolności do pracy. Warto jednak zaznaczyć, że od marca 2020 r. ubezpieczonemu rolnikowi, który jest niezdolny do pracy z powodu zakażenia lub choroby układu oddechowego oznaczonych w zaświadczeniu lekarskim jako U07.1 COVID-19 zgodnie z Międzynarodową Klasyfikacją Chorób i Problemów Zdrowotnych, przysługuje wyższy zasiłek chorobowy - 15 zł za każdy dzień niezdolności do pracy trwającej do $14 \mathrm{dni}^{32}$. Zestawienie kwot świadczenia chorobowego i zasiłku opiekuńczego dla rolników ma jedynie charakter poglądowy. Należy bowiem podkreślić nie tylko odmienną podstawę przysługiwania zasiłku opiekuńczego i inny kwotowy wymiar świadczenia, lecz także szczególny sposób jego finansowania. Zasiłek chorobowy dla rolników ani dotychczas, ani w przyszłości nie może bowiem zastąpić zasiłku opiekuńczego.

Odmienne są również funkcje tych świadczeń. Rolniczy zasiłek opiekuńczy powinien kompensować dochody przy założeniu potrzeby realizacji funkcji wspomagającej proces podtrzymania produkcji rolnej. I choć podobnie jest w przypadku świadczenia chorobowego, to zasiłek opiekuńczy powinien także stanowić zachętę dla rolnika do zaprzestania pracy w działalności rolniczej i podjęcia się opieki nad dzieckiem. Funkcja ta wymaga podkreślenia nie tylko z uwagi na zagrożenia występujące w działalności rolniczej, ale także na ustawowy obowiązek opieki rolników nad tak małymi dziećmi. Warto zauważyć, że rolnicy nie mogą w takim przypadku zatrudnić opiekunki do dziecka, ponieważ jest to przesłanka pozbawiająca ich prawa do zasiłku ${ }^{33}$. Potrzeba podtrzymania produkcji może się też wiązać w tym przypadku z koniecznością zatrudnienia pomocy do pracy w rolnictwie - na czas trwania określonej w ustawie przeszkody. Jest to sytuacja odmienna od położenia typowego pracownika.

Mając na względzie swoistość pracy w działalności rolniczej, można przyjąć, że rolniczy zasiłek opiekuńczy powinien pełnić potrójną funkcję:

31 Kwota we wskazanej wysokości określona została do 1 marca $2021 \mathrm{r}$.

32 Rozporządzenie Ministra Rolnictwa i Rozwoju Wsi z 19 marca 2020 r. zmieniające rozporządzenie w sprawie określenia wysokości jednorazowego odszkodowania z tytułu wypadku przy pracy rolniczej lub rolniczej choroby zawodowej oraz zasiłku chorobowego (Dz. U. poz. 486) weszło w życie z dniem 21 marca 2020 r., z mocą od dnia 8 marca 2020 r.

33 Trzeba mieć tu także na względzie dostępność takich usług na wsi i dochodowość rolników, których w większości nie stać na wynagrodzenie dla opiekunki do dzieci. 
kompensacyjno-wspomagająco-zachęcającą. Obecnie ustalona wysokość zasiłku opiekuńczego nie kompensuje wystarczająco utraconych dochodów $\mathrm{w}$ rolnictwie, a przez to nie zachęca do zaprzestania wykonywania pracy w gospodarstwie na czas opieki nad dzieckiem. Nie umożliwia także rolnikom sfinansowania pracy osoby, która dodatkowo zaangażowana pomogłaby podtrzymać ciągłość produkcji w gospodarstwie rolnym. Wskazane funkcje są ściśle ze sobą powiązane, a zostały w uzasadnieniu do ustawy wprowadzającej analizowane rozwiązanie zastąpione funkcją pomocową - wsparciem finansowym ze strony państwa dla rolników z tytułu zamknięcia placówek szkolnych i wychowawczych w czasie pandemii.

6. Przedstawione rozważania pozwalają na sformułowanie kilku wniosków. Po pierwsze, rolnikom nie przysługiwało dotąd prawo do zasiłku opiekuńczego, toteż przyznanie go wymagało stosownej decyzji legislacyjnej. Ten bezprecedensowy zabieg ustawodawcy został uargumentowany potrzebą wsparcia rolnictwa w dobie COVID-19. Konieczność zapewnienia opieki dla dzieci do lat 8 może być poważną przeszkodą dla rolników podczas wykonywania czynności składających się na prowadzenie działalności rolniczej. Teren gospodarstwa rolnego jest szczególnie niebezpieczny dla małych dzieci. Potrzeba zapewnienia im opieki w czasie zamknięcia szkół i innych placówek opiekuńczo-wychowawczych nie powinna zatem budzić wątpliwości. Działalność rolnicza wymaga od rodziców dużej dyspozycyjności, więc przedstawione w opracowaniu problemy mają szczególne znaczenie dla rodzinnych gospodarstw rolnych.

Po drugie, rozważany zasiłek opiekuńczy jest świadczeniem obowiązującym tylko z powodu zamknięcia placówki szkolno-wychowawczej dziecka do ukończenia 8 lat na skutek wystąpienia sytuacji pandemicznej. Zasiłek ten posiada cechy swoiste, dlatego można go nazwać „,covidowym rolniczym zasiłkiem opiekuńczym”. Świadczy o tym szczególna podstawa jego ustanowienia (tylko przeszkoda związana z COVID-19), okres przysługiwania, szczególny wymiar finansowy świadczenia oraz całkowite finansowanie go z budżetu państwa przy obsłudze dokonywanej przez KRUS.

Po trzecie, przyczyną wprowadzenia zasiłku opiekuńczego była pomoc dla rolnictwa w dobie pandemii. Działalność rolnicza wymaga szczególnych nakładów pracy związanych z koniecznością stałego podtrzymywania produkcji rolniczej. Dobrze to widać w gospodarstwach o zwierzęcym profilu produkcji. W przypadku gospodarstw zajmujących się uprawą roślin nakłady pracy zależą od pór roku. Wiele gospodarstw rolnych w Polsce dywersyfikuje produkcję, toteż zimowy okres wprowadzenia zasiłku dla rolników nie powinien budzić wątpliwości. Pojawiają się one jednak podczas próby oceny 
analizowanego rozwiązania. Rolniczy zasiłek opiekuńczy powinien bowiem spełniać funkcję kompensacyjno-wspomagająco-zachęcającą. Określona dla rolników kwota świadczenia nie pozwala na wystarczającą kompensatę utraconych dochodów i nie pokryje kosztów zatrudnienia dodatkowej pomocy do pracy $^{34}$ na czas trwania przeszkody - konieczności opieki nad dzieckiem z powodu zamknięcia placówki opiekuńczej. Mając na względzie argumentację uzasadniającą wprowadzenie omawianego rozwiązania, można stwierdzić, że zasiłek opiekuńczy pełni dziś jedynie funkcje pomocowe - wsparcie rolnictwa w okresie pandemii. Trzeba przy tym pamiętać, że świadczenie to ma charakter przejściowy, a więc niepewny - mimo że jego obowiązywanie było już w drodze rozporządzeń kilkakrotnie przedłużane ${ }^{35}$.

Po czwarte, dopiero nadzwyczajna sytuacja - ogólnoświatowa pandemia COVID-19 - uwidoczniła w polskim systemie zabezpieczenia społecznego kolejne braki w ochronie rolników. Przyznane świadczenie nie zostało uregulowane w ubezpieczeniu społecznym rolników, a wydaje się ono szczególnie potrzebne w tym sektorze gospodarki. Jak wykazano, jest to istotna kwestia w obliczu konieczności zapewnienia małemu dziecku opieki na niebezpiecznym terenie gospodarstwa rolnego, tak silnie związanym z gospodarstwem domowym, że nie sposób wyznaczyć między nimi granicy.

Rolniczy zasiłek opiekuńczy powinien zachęcać producentów rolnych do zaprzestania pracy w gospodarstwie na rzecz opieki nad dzieckiem niemogącym uczęszczać do żłobka, przedszkola czy szkoły. Problemu nie rozwiąże zajęcie dziecka pracą rolniczą, zwłaszcza z uwagi na wysoką wypadkowość w działalności rolniczej. Zakres pomocy dziecka w gospodarstwie powinien być uwarunkowany jego wiekiem, przy uwzględnieniu potencjalnych zagrożeń. Nie można też zapominać o pozbawieniu dzieci ochrony od wypadków przy pracy w rolniczym ubezpieczeniu społecznym i znacznie zawężonej ochronie gospodarczego ubezpieczenia od następstw nieszczęśliwych wypadków (NNW) ${ }^{36}$. Ochrona ubezpieczeń NNW działa tutaj ex post. Tymczasem dzieciom wiejskim potrzebna jest przede wszystkim ochrona ex ante, czyli zanim dojdzie do niekorzystnego zdarzenia losowego.

Po piąte, uzasadnione jest podjęcie dyskusji nad potrzebą uregulowania zasiłku opiekuńczego w systemie ubezpieczenia społecznego rolników. Nadal bo-

${ }^{34}$ Rolnicy są w tej kwestii od lat traktowani po macoszemu. Szczególnie to widać w przypadku skandalicznie nisko określanego od lat zasiłku chorobowego w kwocie 10 zł za każdy dzień niezdolności do pracy.

35 Ostatnie rozporządzenie przedłużające uprawnienia zostało wydane jak dotąd w marcu 2021 r. - rozporządzenie Rady Ministrów z 12 marca 2021 r. w sprawie określenia dłuższego okresu pobierania zasiłku opiekuńczego w celu przeciwdziałania COVID-19 (Dz. U. poz. 455).

${ }^{36}$ D. Puślecki, Ubezpieczenie od następstw nieszczęśliwych wypadków..., s. 154-155. 
wiem, mimo wprowadzenia rozwiązania szczególnego, istnieje luka w ochronie producentów rolnych w tej materii. Postulat ten nabiera znaczenia w przypadku małych, niewielopokoleniowych gospodarstw rolnych, które nie są w stanie zapewnić dziecku we wskazanych przypadkach zamiennej opieki. Dyskusja powinna jednak dotyczyć nie tylko konkretnych rozwiązań prawno-finansowych, ale także właściwego zakresu ochrony dochodów rolników i ich dzieci w jednym z najniebezpieczniejszych działów gospodarki.

\title{
BIBLIOGRAFIA
}

Biernat P., Gronek E. (2018), Zasiłek macierzyński oraz zasiłek opiekuńczy jako świadczenia pieniężne wypłacane z ubezpieczeń społecznych w ramach ubezpieczenia chorobowego, „Rynek - Społeczeństwo - Kultura” nr 2(28).

Dziubińska-Lechnio E., Kostrzewa M., Kaleta J. (2017), Meritum. Ubezpieczenia społeczne 2017, Warszawa.

Jędrasik-Jankowska I. (2014), Pojęcie i konstrukcje prawne ubezpieczenia społecznego, Warszawa.

Kluszczyńska Z., Koczur W., Roszewska K., Rubel K., Szpor G., Szumilcz T. (2016), System ubezpieczeń spotecznych. Zagadnienia podstawowe, Warszawa.

Król M.A. (2015), Rozwiąania prawne w zakresie zabezpieczenia warunków pracy kobiet $i$ przeciwdziałania wypadkom z udziałem dzieci $w$ rolnictwie $w$ aktach międzynarodowych $i$ wybranych państwach europejskich, „Ubezpieczenia w Rolnictwie. Materiały i Studia" nr 53.

Puślecki D. (2006), Z problematyki prawnej wypadku przy pracy rolniczej, „Prawo i Administracja" t. V.

Puślecki D. (2020), Ubezpieczenie od nastęstw nieszczęśliwych wypadków i chorób dla dzieci rolników ubezpieczonych w KRUS, „Przegląd Prawa Rolnego” nr 1.

Skąpski M. (1999), Wybrane zagadnienia wspótpracy zawodowej rodziców i dzieci, „Ubezpieczenia w Rolnictwie. Materiały i Studia" nr 4.

Szmid K. (2020), Ustawa o szczególnych rozwiązaniach związanych z zapobieganiem, przeciwdziałaniem i zwalczaniem COVID-19, innych chorób zakaźnych oraz wywołanych nimi sytuacji kryzysowych. Komentarz, Warszawa, Legalis.

\section{CHILDCARE ALLOWANCE FOR FARMERS AND HOUSEHOLD MEMBERS INSURED WITH THE AGRICULTURAL SOCIAL INSURANCE FUND}

\author{
Summary
}

The aim of this paper was to answer the question to what extent the unique construction of the right to the childcare allowance, taken over from the general social insurance, provides protection for entities conducting agricultural activity. The author concludes that 
granting farmers the right to the childcare allowance was an unprecedented move on the part of the legislator, justified by the need to support agricultural activity during the period of COVID-19 pandemic. However, the institution of the right to "Covid agricultural carer's allowance" was regulated in a fragmentary way and is only of transitional character, having been established outside the agricultural social insurance system. Due to the small amount of the granted benefit, it cannot perform a compensatory-supportive-incentive function adequately.

Keywords: childcare allowance, social insurance of farmers

\title{
ASSEGNI DI ASSISTENZA PER GLI AGRICOLTORI E I FAMILIARI ASSICURATI PRESSO LA CASSA DELLE ASSICURAZIONI SOCIALI PER GLI AGRICOLTORI
}

\author{
Riassunto
}

L'articolo si propone di rispondere alla domanda in che misura la struttura unica del diritto all'assegno di assistenza, che si basa su quella dell'assicurazione sociale, riesca a tutelare i soggetti che svolgono un'attività agricola. Nella parte conclusiva, l'Autore afferma che concedere l'assegno di assistenza agli agricoltori è stato un intervento senza precedenti da parte del legislatore, spinto dalla necessità di sostenere l'attività agricola ai tempi della COVID-19. Tuttavia, il diritto all'assegno in esame è stato regolamentato in modo frammentario, è di carattere temporaneo ed è stato istituito al di fuori del sistema di assicurazione sociale per gli agricoltori. Visto, inoltre, che l'importo previsto è basso, la sua funzione di compensazione, sostegno e incoraggiamento non verrà esercitata in modo adeguato.

Parole chiave: assegno di assistenza, assicurazione sociale degli agricoltori 